\title{
FOOD SOVEREIGNTY, FOOD SECURITY AND SUSTAINABLE DEVELOPMENT: ENVIRONMENTAL AND ECONOMIC CHALLENGES
}

\begin{abstract}
The discussion, academic research and reflection on policy analysis is focused on the role of the agricultural and agri-food related activities in regard to sustainable development and economic growth. The food sector behaviour is crucial for quality of life in any region and, at the same time, agri-related activities are also responsible for a substantial impact on nature in regard to environmental issues and human activities. It is also true that agricultural activities and food production chains are main players and crucial elements for a sustainable growth process and quality of life in any region.

Trade and international relations can and should be a tremendous opportunity for growth, but economic growth and development with a sustainable environment and quality of life objectives are important challenges, where freedom of choice of individual and collective actions need to be preserved and enhanced. Food sovereignty and food security are recent concepts to be taken into consideration, explored and revisited in regard to models that can provide "benchmarks" to evaluate performances and provide insights for better policies in the future.

Environmental and economic objectives can be convergent and work together, and good examples should be provided, mainly in regard to the development challenges the world is facing. Greater responsibilities are obvious for the main and bigger economies, developed and developing countries, but also at local level. No one can be excluded from the huge scope of challenges the planet and the society will be facing in the nearest future. Global and local perspectives are essential, and food security/food sovereignty analysis is a first step, under the general concern, for a sustainable development process, where freedom of choice and quality of life are clear objectives to be achieved, as strongly as possible.
\end{abstract}

Keywords: food sovereignty, food security, sustainable development, challenge, freedom of choice, quality of life. 


\section{Introduction}

Economic development is still the main challenge the human kind is facing, mainly in regard to the basic needs and sustainability concerns, but immediately linked with freedom of choice and quality of life improvements.

Recently, the concerns about freedom of choice and security in our society are again strongly present, often meaning that more freedom implies less security and/or more security - less freedom. The recent reflection in policy analysis and the role of agriculture in the development process, regarding food security matters, also points out that "security" should mean, most of the times, more freedom of choice and not the reverse. The discussion in this paper will be focused on finding the key aspects and concerns that can be convergent, representing different points of view but essentially looking at the same issues and dimensions that need to be taken into consideration for policy analysis.

Economics and environment can be two different dimensions of the ecosystems on which human kind depends. The first one, immediately related with efficient choices regarding the economic rational, is mainly focused in the short run, and the second (more evident in the long run), looks at the impact of human activity ("footprint" measures) on natural resources. Sustainability is, probably, the "key factor" to be under analysis, dealing with complementary and/or competing issues between economic rationale and environmental impact. Time and space are, probably, the most important variables that need to be taken into the "equation system" analysis dealing with sustainability needs (social and economic rationale, and natural resources use with their respective impacts (over time ad space)).

Sovereignty in food matters appeared with international relevance and institutional normative "wording" exactly at the same time as "food security" concept and definition at the UN/FAO meeting in 1996. This reference is bringing into discussion a new vision of the food system, which is related with the right to produce and consume under a local perspective and eco-related rationale. It was born under a family farming perspective, integrating production and consumption the right to choose, respecting culture, tradition and environment. Most of the time it is viewed as one biased perspective not favourable for trade improvements and modern technology implementation. But let us have a look at the essential aspects of those concerns that can be identifiable as the "core/fundamentals" of this new perspective used for significant social groups. It seems obvious that two aspects precondition the food sovereignty concerns: Freedom of choice and space relations, especially the social relations linked with "power" and "property rights" that are expressed as "territorial considerations."

From social analysis the "territorial notion" has been always polemic. But it is always a relation between a referential space (and time) and an established relationship of certain power "appropriated" for someone. Any society produces a "territory" and depends on a certain "territory". At the same time, freedom of 
choice over a certain space relationship clearly defines degrees of freedom and responsibility for each one of us and for collective actions within a certain society. The food sector and the agricultural sector are among the crucial economic and social areas in the European construction, but they are also responsible for the administration of great share of land resources in any country.

Economic policy, public but also private, should play a determinant role regarding the main sustainability questions in the development process, within the human development systems. Food and agricultural policy in the European Union was one of the most successful cases in the EU integration of solving the "food security equation" by providing guarantees of sufficient food intake of reasonable quality for all in the region. However, the social security systems, social inclusion, public but also private initiatives, have played an important role in providing guarantees of reasonable food security across different societies, regions and families, and as such deserve attention. The interactions between both areas of policy intervention open new opportunities that are now starting to be explored.

The multifunctionality of the agricultural sector was assumed as crucial for development and sustainability objectives. What is not obvious or present in most food policy analyses and case studies are the structural changes of the food systems. According to the author (Carvalho, 2014), European and OECD countries are living in a surplus of output capacity phase, mainly in food production (but also in several other sectors).

Taking this point of view, which was demonstrated at macro and micro levels, the food consumption research area and literature review also provide evidence of the demand constraints at micro and macro levels. For example, the Engler's curve relating income growth to food consumption levels provides evidence of the limits on consumption markets. Many other references can be offered in relation to the demand constraints, but in the current discussion what will be stressed is the need to introduce the notion of "consumption space", regarding markets and development objectives.

Within a development perspective some other referential elements need to be kept in mind. Accordingly with the author's view, based on conceptual and theoretical models, but also real experiences and case studies, the models used stands providing arguments, rationale, facts and empirical evidences showing how important it is to provide the economic policy for the most correct "regulatory environment." In most cases for the markets to function in reasonable conditions, the most efficient system and correct "business environment" should be "pro-market oriented." Regulation and markets are most of the time assumed to be two different approaches to the economic system, the first, based on government intervention and, the second one, resulting from the "natural" interaction of the economic agents. What is today a significantly consensual and convergent perspective is the need to have as much as possible markets working whenever and wherever they 
can function in reasonable conditions, but also the need to have different forms of regulations providing the best "business environment". The most important message is to assume that regulation is most of the time a necessary condition (not sufficient) for success, but regulation that facilitates business and provides "enhanced environment for business" on a market oriented economy.

\section{Analytic structure and methodology}

In this paper the main goal is to look for convergent perspectives/diagnosis in the food system and in the development process, allowing the design and analysis of possible policy solutions to strength food security achievements and sustainability in the development process. "Economy versus environment" challenges are a starting point for looking at the dynamics of the food system and searching for actions at local and global policy measures for sustainable changes able to achieve the most success trend in development and quality of live for a certain referential population (most of the times at country level, but also at regional and local levels). Three different referential models are discussed:

A - Basic Sustainable Development Model,

B - Induced Changes and Innovation Model - general equilibrium perspective; C - Demand Constraints and New Demands.

From the discussion of the three different approaches to better understand and explore alternatives for intervention in the food system, actions and policies, the author provides a short revision of the key concepts and derives some hypotheses to be explored under empirical conditions and testing rationale procedures. To start providing evidences and facts that can support the rationale presented, two study cases are used. One based on the experience of Portugal, a relatively developed country, well "fed" with some of the best food consumption characteristics, but with limits on markets and evolving from an isolated perspective to a very open economy. On the other extreme, there is a very small country in Africa, São Tomé and Principe, one of the poorest countries, but with relatively good conditions in food consumption in the past and today based on a very open and international cooperation and with clear challenges in terms of lacking autonomy and sustainable development processes.

In both country case studies, the international community plays a key role, where demand constraints have been relaxed based on the trade possibilities, but where sustainability and "trade-offs" between economic development, sustainability and freedom of choice (risks and vulnerabilities) need to be considered. The data presented and the arguments discussed previously (based on the third approach, demand constraints and new demands, that are not fully explored here, but deserve some attention in the future), at least show the importance of the international trade. However, the hypothesis of having other solutions to help solve the "demand constraints", such as the importance of the local/global development, cannot be rejected and cannot be tested directly. 
This means that concepts and considerations, such as territorial considerations and sovereignty (freedom of choice under a certain space and time), will stay under theoretical and analytical discussion with great potential for helping to achieve a "better world".

\section{Discussion of the models and revision of key concepts}

Sustainability concerns are not new and can be found in the literature at least since the $19^{\text {th }}$ century (for example with Thomas Malthus, in food matters). Conservation and environmental issues are not exclusive matters from the last decades, but a referential moment was the United Nations Conference on the Human Environment, 1972 in Stockholm.

\section{Referential Model A}

The most traditional and frequent model dealing with sustainability and development can be represented in the Fig. 1 below.

\section{A three dimension model:}

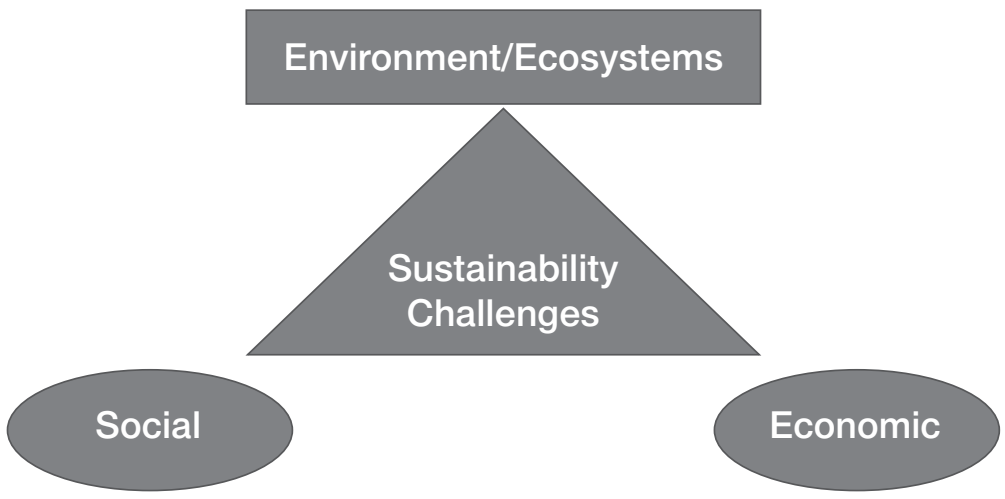

Fig. 1. Referential Models - Model A - Sustainable Development Model.

Source: author's elaboration.

\section{Referential Model B}

The second Model, used in the present analysis, is based on Hayami and Rut$\tan (1985)$ work and hypothesis, with its roots in the idea of the Induced Change rationale in the economy. That is, the technical and institutional changes are always a result of induced process based on economic rationality. The author in his previous work (Carvalho, 2004) also used the same analytic structure, but introduced some important changes, related with the role of markets and governments. First, he considered the markets as an institution (but also more than that), 
meaning that markets are not necessarily a result of human construction but are almost a natural phenomenon which can be found in the nature and other biological systems. Secondly, he considered that governments are also institutions (but also more than that) in the sense that should be viewed as a special type of institutions, first of all, representing a very broad set of institutions in itself and, secondly, with a determinant role in terms of decisions and relevance in defining the rules of the "game." Recently, the discussion evolves, and a broad concept starts to be used, dealing with a notion of "systemic governance" which includes governments but also all other forms of defining decision-making process and respective application and implementation of the decisions assumed by any economic unit, at individual and collective levels and at micro and macro/collective levels. Fig. 2 represents the "state-of-the-art" regarding the previous analysis and more recent applications.

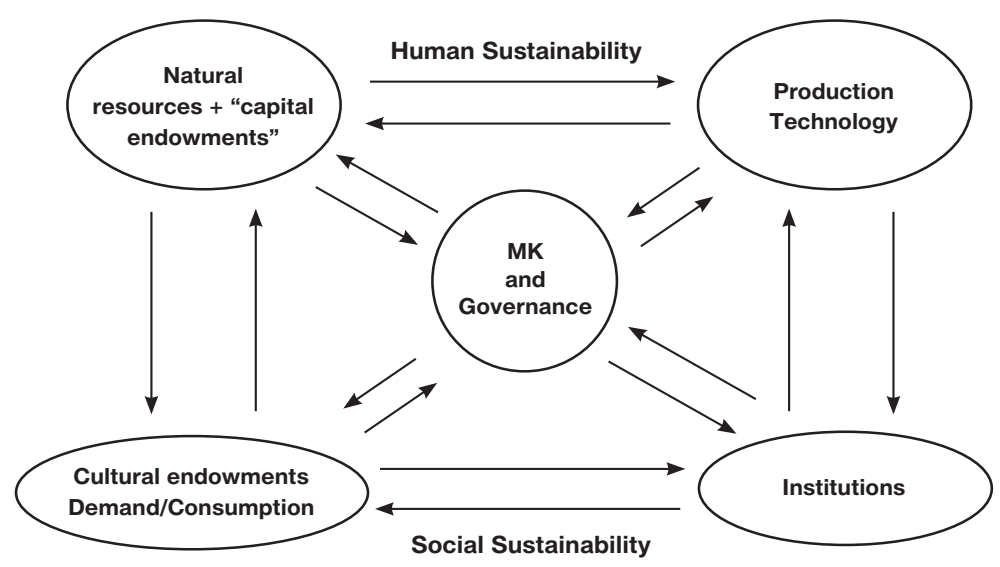

Fig. 2. Referential Models - Model B - Induced Changes and Innovation Model Source: Carvalho (2004) and author's elaboration.

The most recent discussion using the sustainability model and the Induced Innovation Rationale, called ICI - Induced Changes and Innovation Model, which indeed can be viewed as a "general equilibrium model", can be combined to produce a new structure, which allows for a more complete perspective centered on environment/ecology plus a territorial equilibria focus where markets and governance questions should be viewed as part of it. As an alternative, both markets and governance can be included in the institutional factors. The most important issue here is the "merging" effort to join analysis of induced innovation rationale with the "sustainability" dimension.

Fig. 3 below offers this new perspective to be discussed and used for policy analysis and sustainable development inquiries. 
In this new formulation, centered on "ecology" and "territorial equilibrium", supply and demand are considered within its economic rationale, but also within its impact on nature ("footprint") and "institutional environment". Local and global levels need to be considered, mainly in terms of sustainable development issues. The short- and long-run perspectives can be used, but on long-term perspective, environment and territorial equilibria needs to be achieved, and economic and environment matters need to be convergent. In short-run conditions, "trade-off" relations need to be analyzed and considered, since economic results can have important externalities and environmental impact (negative ones) that need to be taken into account as costs associated to the production/economic decisions (which, much of the time, markets cannot take into account).

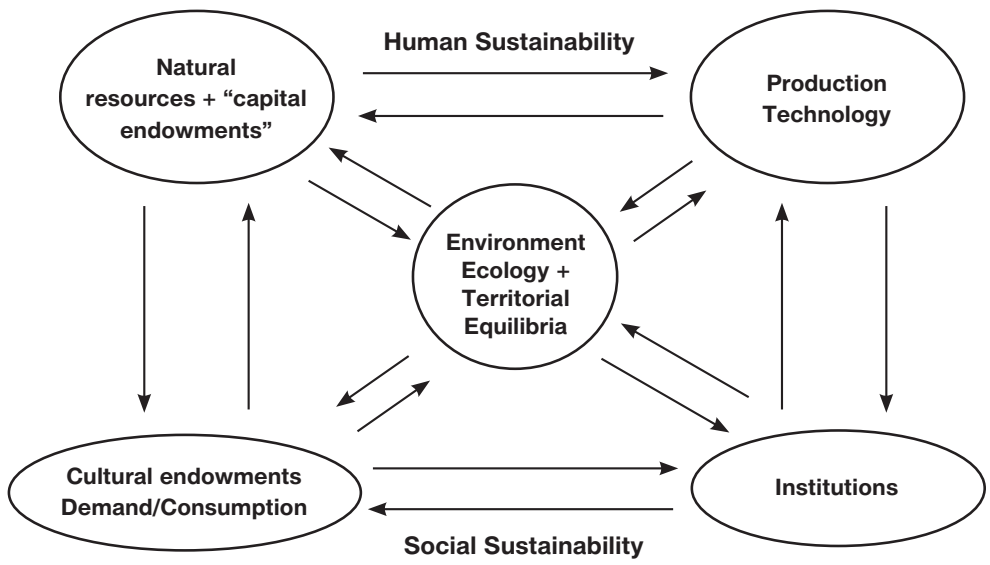

Fig.3. Referential Models - Model B2-Induced Changes and Innovation Model+Sustainability. Source: Carvalho (2004) and author's elaboration.

\section{Referential Model C - Demand Constraints and New Demands}

Demand is the new "driving force" in the modern economy, where production capacity is now beyond consumption possibilities. New demands appear every day, but some constraints are present, such as the "time frame" and the "value of time".

The author (Carvalho, 2014), provided a general definition for "production", where a "modern view" is needed to include a chain perspective, in which the last step is the "production of utility", present or future utility to someone, that is, the consumption process in itself. Indeed, with that perspective, "consumption" is the last step in the production chain and chain value creation.

Chain value studies are becoming more important every day, allowing to focus on the essential objective, "creation of value" and, at the same time, looking 
at the market functioning characteristics, power relations along the chain and respective distribution of the value creation process.

In the food sector, the EU-15 is clearly achieving a new equilibrium in production and consumption, with almost no growth on both sides at global levels in relative terms. Demand growth depends on more consumers (population), and per capita income growth/consumption growth per capita. In the food sector, in per capita terms, for many products, the "plateau" and/or decreasing levels of consumption are evident (Engel's law, 1857). The "saturation levels" in consumption is becoming more evident in many products and in food overall, since there is a limited capacity to consume. In other words, it can be said that food is the first consumption need to be "solved" in any development process. There are specific characteristics in the food production process, but demand behaviour also has specific characteristics. For example, it is well known that food demand is price inelastic. It is also well known that the budget share in food for families of high income is much lower than those with low income levels. Income elasticities for many products, for example new products entering the market, will tend to have a "logistics curve" behaviour ("Pacheco's curve"). But for all food products, and for aggregated food item, a high income level means also low income elasticity. In real context, there is no "space" for significant growth in food demand at high income levels. This also means that industrialized economies, more developed ones, will not provide significant food market growth and will always have lower growth with higher income levels.

The analysis of demand constraints and respective analytic models in regard to technical /technological and institutional change processes can be explored to provide a powerful tool to understand the food system behaviour. It is also important to look at the "theory of constraints" (TOC) as a paradigm in management, looking always to any manageable system as being limited in achieving more of its goals by a very small number of constraints. All those perspectives can be connected and explored in more detail. Here the focus is to identify and point out some of the measures for food policy that can help providing "demand constraints relaxation." Again, it is assumed that in any situation there is a possibility to "relax" constraints and into a systemic view there is always some (few) factors that are the most limitative. For a broad categorization it is possible to point out the following measures/type of measures (for food policy intervention);
A. enlargement of market measures in general (income distribution possibilities, for example);
B. logistics and information;
C. infrastructures;
D. trade improvement measures, especially the international trade;
E. processing and conservation;
F. adding value strategies;
G. co-generation of value. 
The great majority of the factors pointed out above are quite clear in terms of demand impact possibilities. Here a brief comment is provided in regard to the last ones. Today, many of the possible strategies to "create value" in the food and agricultural systems will have to rely on other dimensions beyond nutritional value of food (such as ludic, historical, cultural, ecological and sustainability dimensions) and/or exploring other "uses" for the outcomes of the agricultural sector, such as non-food utilization industries and the "services of nature" related to the ecological and sustainability/environmental dimensions.

The last one, co-generation of value, very much related with local and regional development objectives is based on the "closed" overall cycle of production, utility generation and immediate/short chain consumption by final consumers. That is, there are possibilities to generate value with food production, availability of land, labour and "local consumption space", where the ones involved in the value creation can greatly participate in its local consumption with short chains. Value created is reflected immediately in "income generation", with increasing demand, turning potential demand into "effective demand." That means, the production is very well connected with consumption, which is realized with short chain and local/regional based consumption.

\section{Alternatives for intervention based on the models presented: concepts and hypotheses to be explored}

All those concepts and concerns about environment and sustainability derived from the United Nations Conference on Human Environment in 1972 were used and received increasing attention. Recently, the climate change evidence, biodiversity loses and other ecosystem challenges have been under a strong pressure from the public and scientific evidences raised by research. Along with those new challenges raised, mainly due to and as a consequence of human impact on the environment, social and economic problems continue to deserve a special attention, mainly where lack of improvements seems to be permanent and related to the human basic needs such as enough "food" and satisfaction of basic nutritional needs.

Food and nutritional security is a very old dilemma to the human society, however, it is necessary to recognize the huge improvements in the food systems, mainly between 1950s and 1990s, but, at the same time, it is important to recognize, the new paradox (contradiction of the food system not solved and with permanent character) after mid-1980s, and definitely after 1990s where there is enough food to feed everyone in the world, but the estimations for hunger continue to range from 800 million to one billion people in the last 20 years (Carvalho, 2013; FAO).

In regard to several "paradoxes" in the food systems, the conceptual evolution around hunger and food systems dynamics "produced" some new "approaches." It is consensual to say that much more importance is given today to a systemic 
agricultural research approach and food policy intervention, and a clear "chain value analysis" related with market functions and regulation needs. The first one, links immediately with the increasing consciousness of the "multi-functionality" outcomes from agricultural activities and, the second, beyond the need of an integrated analysis, looking to market functions, efficiency conditions but also benefits (and created value) distribution along the chain value.

Two different concepts appeared in the international arena, which might be considered crucial for sustainable development goals. The first one, is the food security concept, linked with human security concerns very much present after the II World War. The second one, is the "food sovereignty" linked with freedom of choice (or lack of freedom) in production and consumption, basically under a family farming structure. Both receive special attention and were acknowledged at the 1996 World Forum (FAO World Food Summit).

The World Food Summit (FAO, 1996) referential definition is the following: "Food security exists when all people, at all times, have access to sufficient, safe and nutritious food to meet their dietary needs and food preferences for an active and healthy life." Based on this worldwide accepted definition and follow-up discussion, the author proposed a similar definition with a clear determination of axis for analysis and intervention, such as the following: Food security means ability to access food in physical and economic terms to achieve a healthy diet in permanent and continuous way. This implies on diminishing risks and uncertainties in the food system, at least in the following dimensions:
A. availability;
B. access;
C. consumption/quality, efficiency, nutritional and utilization forms;
D. stability;
E. vulnerability and resilience of the food systems.

Food sovereignty indeed appeared very much motivated by the failures of previous policies, appealing to productivity growth and trade, but failing agricultural development and sustainable development, very much global and corporate based regime (what was termed the "corporate food regime"). Sometimes it can be considered as going beyond food security concept, but what is important to consider here are the common roots and goals. We should start with the most common definition (Wikipedia 2016 - www.wikipedia.org/wiki/ food_sovereignty):

"Food sovereignty is the right of peoples to healthy and culturally appropriate food produced through ecologically sound and sustainable methods, and their right to define their own food and agriculture systems. It puts those who produce, distribute and consume food at the heart of food systems and policies rather than the demands of markets and corporations. It defends the interests and inclusion of the next generation. It offers a strategy to resist and dismantle the current corporate trade and food regime, and directions for food, farming, 
pastoral and fisheries systems determined by local producers. Food sovereignty prioritizes local and national economies and markets and empowers peasant and family farmer-driven agriculture, artisanal fishing, pastoralist-led grazing, and food production, distribution and consumption based on environmental, social and economic sustainability".

According to "La Via Campesina" (in www.foodsecurecanada.org/whowe-are/what-food-sovereignty, 2016, March) "Food Sovereignty is the right of peoples to healthy and culturally appropriate food produced through ecologically sound and sustainable methods, and the right to define their own food agricultural systems."

What can be said in a very short definition is that food sovereignty refers to the right to produce food on one's own territory.

Looking at both definitions and origins, it is clear that they seem clearly different, however, diminishing risks and uncertainties (security) and freedom of choice associated with development, growth, and sustainability, recalls the needs to achieve higher security levels (and respective public and private policy needs), which implies providing higher protection, autonomy to people, and lower vulnerability of systems.

Without going into deep details, what seems obvious is the need to consider time and space factors in both definitions, and immediately the need to consider the "territorial" dimension in the food systems.

The notion of "territorial dimension" was always polemic. But it is always a relation between a certain space (and time) and an established relationship of certain power "appropriated" for someone. What is extraordinary in relation to the "territorial notion" is the linkage with any society and human behaviour "any society produces a territory and depends on a certain territory".

From the international discussion and evolution of concepts, our objective of showing "common grounds" and "common roots" as regards development and sustainability objectives and interfaces with environment and economic relations, points out that territorial questions need to be considered central to the discussion and immediately to the sovereignty (and/or the freedom of choice over a certain space) dimension. Food security and food sovereignty discussion are good examples of different approaches to the same type of concerns which are crucial and also central to any sustainable development policy. Indeed, risks and uncertainties in the food system (food security) is already a sufficient umbrella including all the other concerns, but different approaches and specifications also draw attention to specific aspects that need and deserve more attention.

Another important consideration derived from the previous discussion, with the experience of using the different models presented, is the need to look at the local/global development linkages and balance. Demand constraints relaxing measures (globalization) and technology changes are at the center of the development process in the industrialized economies, but for an inclusive develop- 
ment (and sustainable) dimension, but also to solve global demand constraints, which are now obvious in the EU-15 space (and other more developed economies), local development is a necessary condition.

Local/global relation analysis platform is certainly an important benchmarking initiative, promoting an inclusive and sustainable development process. Food systems are a good starting point to focus on relevant economic relations that need to be well known, such as demand constraints rationale, the local development needs without diminishing the needs for more international relationships.

\section{Cases studies for food policy: food sovereignty, food security and sustainable development}

The literature review is already well served with several references related to those problems, and more recently with food sovereignty issues, research and discussions. It is useful to note that this notion is entering the political arena, i.e. the governmental policy, specifically the food policy agenda. In September 2008 one country, Ecuador, became the first to introduce this concern into the constitution, and many others did the same afterwards, e.g. Venezuela, Mali, Bolivia, Nepal, Senegal and Egypt (2014 constitution), according to Wikipedia information. This issue should be also stressed in Europe. In 2011, Austria held a huge meeting, with more than 34 countries involved and more than 400 people from different origins to discuss food sovereignty in Europe. What was evident was the failure of the food system in many situations, and the failure of the most common policies of production growth. The Green Revolution success story, mostly related with plant breeding and crop yields growth (mainly between 1960s and 1980s), is the most significant example of the need for an integrated policy and global development perspective, but based on local grounds. It was criticised and the criticism needs to be better understood.

In the present effort, two different countries are studied and discussed. One European country, Portugal, which will be used as an example for more developed economy, and a very small country, a developing economy in Africa, São Tomé and Principe. Both countries show great improvements in the agri-food system and/or food consumption, both are very open to stronger international relations and trade and both show signs of policy concern in relation to risks and vulnerabilities in the food systems.

\section{Portugal case study overview}

Portugal last year's growth in the agri-food sector and trade was impressive.

For the first time in many decades, trade balance was positive from 2013 to 2015, and the agri-food sector contribution was important.

The challenges still continue in regard to export growth and import substitution (under a crisis perspective, since it is not possible and not feasible to have all the "economic space" with trade surplus). However, it is important to stress 
the degree of openness of the economy and specifically in regard to the agri-food related sectors. Table 3 below clarifies this point presenting the ratio for "economy openness" (which means the relation of the export+import value in relation to gross value added in each sector).

Table 1

Comparative growth rates for the agroforestry and fisheries sector and the economy in 2000-2011 period (\% in current prices)

\begin{tabular}{lcc}
\hline & Imports & Exports \\
Agriculture & 4.0 & 10.9 \\
Fisheries & 4.3 & 6.1 \\
Food, beverage and tobacco industries & 4.8 & 8.0 \\
Forestry & -1.8 & 5.0 \\
Forest industries & 1.6 & 4.4 \\
Agri-food sector & 4.6 & 8.2 \\
Forest sector & 1.1 & 4.4 \\
Agroforestry and fisheries sector & 3.8 & 6.2 \\
Economy - goods & 2.3 & 4.0 \\
Economy - goods and services & 2.6 & 4.6
\end{tabular}

Source: GPP estimates from National Accounts, INE in Carvalho (2014).

Table 2

Self-sufficient rates in Portugal, before and after the EU integration, measured in \% of local production in regard to consumption (GAA\% - degree of self-sufficiency)

\begin{tabular}{lcc}
\hline & Before the EU - GAA \% & After the EU - GAA\% \\
\hline Cereals & 47 & 27 \\
Wheat & 37 & 11.5 \\
Rice & 63 & 53 \\
Maize & 47 & 29.2 \\
Roots and tubers & 94.2 & 58.7 \\
Hortic+fruit & 178.8 & 166.4 \\
Bovine meat & 96.2 & 52.2 \\
Swine meat & 100.7 & 51.3 \\
Chicken meat & 100 & 93 \\
Ovine+goats & 100 & 79.8 \\
Milk & 100 & 106.2 \\
Fish & 102.1 & 41.1
\end{tabular}

Source: data from GPP/Ministry of Agriculture in Carvalho (2014). 
Table 3

Degree of openness of selected agri-industrial sectors for Portugal

\begin{tabular}{cccccc}
\hline Econ.total & $\begin{array}{c}\text { Farm prod., } \\
\text { forest } \\
\text { and fish }\end{array}$ & $\begin{array}{c}\text { Food+bev., } \\
\text { and tobacco } \\
\text { industry }\end{array}$ & Textiles & $\begin{array}{c}\text { Wood material, } \\
\text { paper and } \\
\text { printing } \\
\text { services }\end{array}$ \\
\hline 1995 & 62.63 & 46.6 & 221.29 & 212.47 & 142.34 \\
2000 & 71.28 & 63.71 & 219.2 & 259.22 & 160.66 \\
2005 & 67.22 & 77.16 & 205.15 & 246.13 & 178.01 \\
2010 & 71.19 & 112.97 & 257.77 & 272.74 & 202.15 \\
2012 & 80.33 & 131.07 & 302.44 & 277.27 & 239.82 \\
2013 & 81.9 & 121.8 & 308.95 & 284.69 & 247.55 \\
\hline
\end{tabular}

Source: Pordata (2016) and author's data study.

The first column shows the global situation for the economy, as a reference, but the following columns show the agri-food related sectors, strongly open, above the average and growing significantly.

\section{São Tomé and Principe case study overview}

São Tomé and Principe is a very small country in the middle of the Atlantic, on the equator, about $500 \mathrm{~km}$ off the West African cost. It is a very interesting country from the edaphoclimatic point of view with rainfall varying from less than $800 \mathrm{~mm}$ to more than $3,000 \mathrm{~mm}$. It is a country with a population getting close to 200 thousand people, growing significantly but with relatively good index of well-being and life conditions (in 2000 life expectancy at birth was 65.1 years, while the average for the world was 66.9). It is also a country with very low per capita income, but with very good conditions for agricultural and food production. However, food consumption and nutritional situation is still very challenging for many families.

The Center for Tropical Agriculture Research - Cooperation and Development (CIAT-CD)/University of Lisbon, today with the support from the Network for Food Security and Sustainable Development (REDISA-CPLP), was able to promote several studies on food consumption and food policy in this country. Table 4 is a good example of those studies which, in general, show a significant improvement in food consumption.

However, food imports, including international food aid, are still an important source of available food consumption, which affects consumption habits and local production.

The evolution of food consumption needs to be evaluated, not only as regards global consumption levels but also other aspects, such as local impact and interaction with local production possibilities, especially given that habits develop contrary to the base of natural resources. 
Table 4

Daily consumption evolution in caloric, protein and fat contents, in per capita terms, EMD equivalent man per day, between 2002 and 2014

\begin{tabular}{cccccc}
\hline Local & Year & $\begin{array}{c}\text { Calories } \\
(\mathrm{kcal} / \mathrm{EM} / \text { day })\end{array}$ & $\begin{array}{c}\text { Proteins } \\
(\mathrm{g} / \text { EM/day })\end{array}$ & $\begin{array}{c}\text { Fat } \\
(\mathrm{g} / \mathrm{EM} / \text { day })\end{array}$ & Observations \\
\hline Água-Grande & 2002 & $2,682.1$ & 113.7 & n.d. & Santo S. (2008) \\
Água-Grande & 2004 & $2,780.08$ & 94.94 & n.d. & Tavares (2005) \\
Água-Grande & 2008 & $3,354.4$ & 147.3 & 23.73 & Santo S. (2008) \\
Água-Grande & 2011 & $2,650.75$ & n.d. & n.d. & Almeida (2011) \\
Água-Grande & 2014 & $3,601.26$ & 125.21 & 95.86 & Silva (2014)
\end{tabular}

Source: Silva (2014); data obtained from different research work performed at CIAT-CD/REDISA-CPLP.

Table 5

Daily consumption evolution in kcal per capita per day in STP, between 2001 and 2010, with classification of the origin of products, of national or international origin, local production and imports

\begin{tabular}{lcccccccccc}
\hline \multicolumn{1}{c}{ Kcal/day/Years } & 2001 & 2002 & 2003 & 2004 & 2005 & 2006 & 2007 & 2008 & 2009 & 2010 \\
\hline $\begin{array}{l}\text { National products } \\
\text { (kcal/day) }\end{array}$ & 1,514 & 1,428 & 1,398 & 1,159 & 1,163 & 2,031 & 1,342 & 1,399 & 1,316 & 1,250 \\
$\begin{array}{l}\text { Imported products } \\
\text { (kcal/day) }\end{array}$ & 1,082 & 1,320 & 968 & 1,133 & 1,639 & 1,322 & 1,279 & 1,329 & 1,764 & 1,809 \\
Total & 2,596 & 2,748 & 2,366 & 2,292 & 2,802 & 3,353 & 2,621 & 2,728 & 3,080 & 3,059 \\
$\begin{array}{l}\text { National } \\
\text { products (\%) }\end{array}$ & 58.32 & 51.97 & 59.09 & 50.57 & 41.51 & 60.57 & 51.20 & 51.28 & 42.73 & 40.86 \\
$\begin{array}{l}\text { Imported } \\
\text { products }(\%)\end{array}$ & 41.68 & 48.03 & 40.91 & 49.43 & 58.49 & 39.43 & 48.80 & 48.72 & 57.27 & 59.14 \\
\end{tabular}

Source: INE-STP in Silva (2014).

Table 5 compares local and international food sources for the first decade of the $21^{\text {st }}$ century.

Table 6, below, also provides information on caloric intake (2014), protein and fat consumption levels, looking at the general situation, but also at the two most important districts, representing more than $50 \%$ of the total population. What can be seen is a very good global situation with more than 3,000 kilocalories per capita per day of food availability.

Both tables are consistent showing a growing share of international food supply, more or less changing in 10 years from 60:40 to 40:60 ratios between local supply and international supply. Last table shows that this ratio continues recently. Protein sources are clearly more important for local reference, but for fat sources the reverse holds. 
Table 6

Daily consumption in kcal, proteins and fat in STP for two different districts, (the two most populated), Agua Grande (73,000 inhabitants) and Mé-Zochi (45,000 inhabitants), representing more than 50\% of the total population, in terms of national products and imported products in 2014

\begin{tabular}{|c|c|c|c|c|c|c|c|c|c|}
\hline \multirow{3}{*}{ Consumption } & \multicolumn{3}{|c|}{ Água-Grande } & \multicolumn{3}{|c|}{ Mé-Zóchi } & \multicolumn{3}{|c|}{ General } \\
\hline & Calories & Protein & Fat & Calories & Protein & Fat & Calories & Protein & Fat \\
\hline & $\begin{array}{l}\mathrm{kcal} / \\
\mathrm{EM} / \mathrm{d}\end{array}$ & $\mathrm{g} / \mathrm{EM} / \mathrm{d}$ & $\mathrm{g} / \mathrm{EM} / \mathrm{d}$ & $\begin{array}{l}\mathrm{kcal} / \\
\mathrm{EM} / \mathrm{d}\end{array}$ & $\mathrm{g} / \mathrm{EM} / \mathrm{d}$ & $\mathrm{g} / \mathrm{EM} / \mathrm{d}$ & $\begin{array}{l}\mathrm{kcal} / \\
\mathrm{EM} / \mathrm{d}\end{array}$ & $\mathrm{g} / \mathrm{EM} / \mathrm{d}$ & $\mathrm{g} / \mathrm{EM} / \mathrm{d}$ \\
\hline $\begin{array}{l}\text { National } \\
\text { prod. }\end{array}$ & $1,473.47$ & 76.9 & 30.93 & $1,442.08$ & 69.55 & 28.54 & $1,457.775$ & 73.225 & 29.735 \\
\hline $\begin{array}{l}\text { Imported } \\
\text { prod. }\end{array}$ & $2,127.79$ & 48.33 & 64.95 & $1,924.86$ & 40.93 & 61.92 & $2,026.325$ & 44.63 & 64.835 \\
\hline Total & $3,601.26$ & 125.23 & 95.88 & $3,366.94$ & 110.48 & 90.46 & $3,484.1$ & 117.855 & 94.57 \\
\hline $\begin{array}{l}\text { National } \\
\text { prod. }(\%)\end{array}$ & 40.92 & 61.41 & 32.26 & 42.83 & 62.95 & 31.55 & 41.84 & 62.13 & 31.44 \\
\hline $\begin{array}{l}\text { Imported } \\
\text { prod. }(\%)\end{array}$ & 59.08 & 38.59 & 67.74 & 57.17 & 37.05 & 68.45 & 58.16 & 37.87 & 68.56 \\
\hline
\end{tabular}

Source: Silva (2014).

There is no doubt that international trade plays a very important role in food supply. The questions now are inevitably related to the impact on local production and economic development, mainly in relation to the national food production systems. The answer is not straightforward and deserves future attention.

\section{Conclusions}

The article broady discusses the relevant aspects under the theme: "economy versus environment - competitiveness or complementarity", basically linked to the food security questions and concerns. The evidence of the "food factor", as a necessary condition for sustainable development, was presented looking at different development models and concept evolution over time. The need for different approaches and perspectives can be justifiable, but it is important to look at the common grounds and concerns. Freedom of choice, welfare and sustainable development should converge in food terms. Looking at the international opportunities, trade is playing an important contribution, but demand constraints should be overpassed looking also at other approaches such as promoting local development alternatives.

The two country cases stress the relevance of the international relations and trade for food availability and consumption. However, those examples also stress the need to look carefully at the risks and vulnerabilities of the food systems and at the need of exploring food policy interventions aiming at local/ global sustainable development dynamics. 


\section{References}

ANSA - Agência Nacional de Segurança Alimentar de Cabo Verde (2013). Anuário de Segurança Alimentar de 2010-11. Praia, Cabo Verde.

Baleiras, R.N. (2014). Território e Desenvolvimento Económico: Falhas Institucionais (Territory and Economic Development: Institutional Failures). Publicação Ocasional do CFP (Ocasional Paper of the CEF) - Conselho das Finanças Públicas (Council of Public Finance). N. 3/2014. Lisboa.

Carvalho, B.P. de et al. (2004). Cooperação e Desenvolvimento: Oportunidades e Desafios para o Século XXI . Série de Estudos de Desenvolvimento e Gestão de Sistemas, vol.10(3). ISA/CIAT- Instituto Superior de Agronomia, Secção de Agronomia Tropical - Departamento de Agro-Indústrias e Agronomia Tropical da Universidade Técnica de Lisboa e Centro de Investigação de Agronomia Tropical - Cooperação e Desenvolvimento. Lisboa.

Carvalho, B.P. de, Costa, D., N. Carvalho (2009). Global Challenges and Local Solutions: Wine Sector Changes in Europe and in Portugal. IAMA, $19^{\text {th }}$ Annual Forum and Symposium. Budapeste. Hungary.

Carvalho, B.P. de, Costa, D., Leite, I. e. (2011). Global Food Outlook: Global Challenges and Local Solutions. IFAMA, $21^{\text {st }}$ Annual World Forum and Symposium. Frankfurt, Germany.

Carvalho, B.P. de (2012). Food Security: Global Challenges and Local Solutions. SEDGES Série de Estudos de Desenvolvimento e Gestão de Sistemas, vol. 18(3). ISA/CIAT Instituto Superior de Agronomia Tropical. Centro de Investigação de Agronomia Tropical - Cooperação e Desenvolvimento. Paper presented at XIII World Congress of Rural Sociology, 29 July up to 4 August 2012. Lisbon (http://irsa2012.com/event/wcrs-2012/).

Carvalho, B.P. de (2013). Science Meets Reality: Economic Efficiency, Markets, Institutions and Food Security. International Journal on Food System Dynamics 4(2), pp. 88-105. University of Bonn. Alemanha.

Carvalho, B.P. de (2014). Regulations, Markets and Economic Efficiency: Sustainable Development and Food Security. Warsaw: Institute of Agricultural and Food Economics National Research Institute.

FAO, Food and Agriculture Organization of the United Nations (2002). Trade Reforms and Food Security. Economic and Social Economic Department. FAO Document Repository, PDF version (available in www.fao.org, link described below).

FAOSTAT 2012 and 2013. On line data bases.

FAO (2009-12). The State of Food and Agriculture. Rome.

FAO (2010-12). The State of Food Insecurity in the World. Rome.

Ferrão, J.E.M. (2005). A Aventura das Plantas e os Descobrimentos Portugueses. Edição do IICT - Instituto de Investigação Científica Tropical, Fundação Berardo e Chaves Ferreira - Publicações S.A. Lisboa. (The Adventure of Plants and the Portuguese Discoveries booklet in English on a condensed version is published by the same author).

Hayami, Y., Ruttan, V.W. (1985). Agricultural Development: an Internacional Perspective. Baltimore and London: The John Hopkins Univesity Press.

Maxwell, S., Frankenberger, T. (1992). Household Food Security: Concepts, Indicators and Measurements. A Technical Review. Unicef, New York, IFAD, Rome. (www.ifad.org/ hfs/tools/hfspubindex.htm). 
Mellor, J.W., Johnston, B.F. (1984). The World Food Equation: Interrelationships among Development, Employment and Food Consumption. Journal of Economic Literature, vol. 22, pp. 531-74.

PNUD (1994). Relatório do Desenvolvimento Humano 1994. Publicado para o Programa das Nações Unidas para o Desenvolvimento pela Tricontinental Editora, Lisboa.

Espirito Santo, S., Carvalho, B.P. de. (2012). Food Consumption, Food Chains and Market Evolution in São Tome e Principe. Proceedings of the $6^{\text {th }}$ International European Forum Igls Forum in Systems Dynamics and Innovation in Food Networks 2012. University of Bonn.

Simon, G-A. (2012). Food Security: Definition, Four Dimensions, History. University of Roma Tre. Faculty of Economics. Master in Human Development and Food Security. Rome. (www.fao.org/filesadmin/templates/ERP/unit/F\$D.pdf)

Silva, C. (2014). Segurança Alimentar em São Tomé e Principe: Estudo de Caso nos Distritos de Agua-Grande e Mé-Zochi. Dissertação de Mestrado em Eng. Alimentar. Lisboa: Instituto Superior de Agronomia. Universidade de Lisboa.

UNDP (2003). Commission on Human Security. Human Security Now. New York.

World Bank (1986). World Development Report. Washington D.C.

World Bank (2000). Cabo Verde Study on Food Security and Regulatory Agency Needs. Basic study supporting the creation of ANSA - Agência de Segurança Alimentar em Cabo Verde in 2002. (Project leader: Bernardo Pacheco de Carvalho).

Digital references:

http://www.fao.org/docrep/w7442e/w7442e04.htm (accessed on 09.03.2015): Chapter 2.

Food security: concepts and measurement.

http://cultivarbiodiversidade.blogspot.pt/2012/09/conceito-de-soberania-alimentar.html (accessed on 23.03.2015).

http://www.acordinternational.org/acord/pt/acord/pt/nossas-actividades/meios-de-subsistn-

cia-e-soberania (accessed on 23.03.2015).

http://www.realimentar.org/v1/ (accessed on 23.03.2015).

http://pordata.pt

http://www.sho.int/mediacentre/factsheets/fs311/en/

http://www.unep.org/Documents.Multilingual/Default.asp (accessed on March 2016)

http://www.wikipedia.org/wiki/food_sovereignty (accessed on March 2016)

http://www.foodsecurecanada.org/who-we-are/what-food-sovereignty (accessed on March, 2016). 
Lizbona

\title{
SUWERENNOŚĆ ŻYWNOŚCIOWA, BEZPIECZEŃSTWO ŻYWNOŚCIOWE I ZRÓWNOWAŻONY ROZWÓJ: WYZWANIA ŚRODOWISKOWE I GOSPODARCZE
}

\begin{abstract}
Abstrakt
Proponowana dyskusja, badania naukowe i rozważania dotyczace analizy politycznej skupiaja się na roli działalności $w$ sektorze rolnym i rolno-spo$\dot{z} y w c z y m$ na rzecz zrównoważonego rozwoju $i$ wzrostu gospodarczego. Sektor żywnościowy ma kluczowe znaczenie dla jakości życia w każdym regionie, a jednocześnie działania zwiąane z rolnictwem mają znaczny wpływ na kwestie środowiskowe i działalność człowieka. Prawda jest również, że działania rolnicze $i$ łańcuchy produkcji żywności to główni gracze i kluczowe elementy $w$ procesie zrównoważonego rozwoju i jakości życia $w$ każdym regionie.

Relacje handlowe $i$ międzynarodowe moga i powinny zapewniać możliwość wzrostu, a wzrost $i$ rozwój gospodarczy, majacy na względzie cele $w$ zakresie zrównoważonego środowiska i jakości życia, to istotne wyzwania, w ramach których należy utrzymywać $i$ wzmacniać wolność wyboru i działania indywidualne oraz grupowe. Suwerenność żywnościowa i bezpieczeństwo żywnościowe to zupetnie nowe koncepcje, które należy rozważyć, zbadać $i$ zrewidować, biorac pod uwage modele mogace dostarczyć „,punktów odniesienia” dla lepszej polityki w przyszłości.

Cele środowiskowe i gospodarcze moga być spójne, należy również zapewnić dobre przykłady zwłaszcza w odniesieniu do wyzwań rozwojowych, jakim świat stawia czoło. Szerszy zakres obowiązów jest oczywisty w przypadku głównych $i$ większych gospodarek, krajów rozwiniętych i rozwijajacych się, ale również na poziomie lokalnym. Nikogo nie można wykluczyć zogromnego zakresu wyzwań, jakim nasza planeta i społeczeństwo będa musiały stawić czoła $w$ niedalekiej przyszłości. Perspektywa globalna i lokalna sa niezbędne, a analiza bezpieczeństwa żywnościowego / suwerenności żywnościowej to pierwszy krok w ramach ogólnej troski o proces zrównoważonego rozwoju, gdzie wolność wyboru i jakość życia stanowią wyraźne cele do osiagnięcia $w$ możliwie najszerszym zakresie.
\end{abstract}

Słowa kluczowe: suwerenność żywnościowa, bezpieczeństwo żywnościowe, wyzwanie, wolność wyboru, jakość życia.

Accepted for print: 30.05 .2016$.

Unless stated otherwise all the materials on the website are available under the Creative Commons Attribution 3.0 Poland license. Some rights reserved to the Institute of Agricultural and Food Economics - National Research Institute.

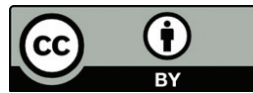

